JURNAL ILMIAH ELEKTRONIKA DAN KOMPUTER, Vol.13, No.2, Desember 2020, pp. 169 - 181

p-ISSN : 1907-0012 (print)

e-ISSN : 2714-5417 (online)

http://journal.stekom.ac.id/index.php/elkom

- page 169

\title{
SISTEM PENDUKUNG KEPUTUSAN PEMILIHAN OBJEK WISATA MENGGUNAKAN METODE AHP BERBASIS JAVA
}

Study Kasus:Dinas Kebudayaan, Pariwisata, Pemuda \& Olahraga Kabupaten Aceh Tengah

Richasanty Septima $S^{1}$

${ }^{1}$ Fakultas Teknik, Program Studi Teknik Informatika, Universitas Gajah Putih

Belang Bebangka, Takengon, Aceh Tengah, e-mail: richaseptima@gmail.com ${ }^{1}$

\section{ARTICLE INFO}

Article history:

Received 30 September 2020

Received in revised form 2 Oktober 2020

Accepted 10 Oktober 2020

Available online 1 November 2020

\begin{abstract}
Department of Culture , Tourism , Youth and Sports Central Aceh district especially in tourism is in charge of managing and developing infrastructure for tourism, the selection of a tourist attraction right capable of giving the best decision with the information on the sights with AHP ( Analytical Hierarchy Prsocess ) that match the criteria , Election Decision Support System using AHP Attractions Java based, Using Netbeans and MySQL as data storage .
\end{abstract}

Keywords : election attractions, ahp methods, Java , MySQL

\section{PENDAHULUAN}

Salah satu permasalahan pengambilan keputusan yang dihadapkan pada berbagai kriteria adalah proses pemilihan objek wisata. Banyak metode yang dapat digunakan dalam sistem pengambilan keputusan. Salah satu metode tersebut yang digunakan dalam penelitian ini adalah metode Analytical Hierarchy Process (AHP). Konsep metode AHP adalah merubah nilai-nilai kualitatif menjadi nilai kuantitatif. Sehingga keputusan-keputusan yang diambil bisa lebih obyektif. Metode AHP mula-mula dikembangkan di Amerika pada tahun 1970 dalam hal perencanaan kekuatan militer untuk menghadapi berbagai kemungkinan.

Permasalahan yang sering muncul masih banyak orang yang berwisata tapi malah menimbulkan beban pikiran baru. Berwisata juga merupakan kebutuhan jasmani yang penting tanpa kita sadari. Karena dengan berwisata kita dapat menghilangkan penat akibat aktivitas selama seharian. Pemilihan objek wisata yang tepat juga berpengaruh dalam hal ini. Oleh karena itu menyadari betapa pentingnya memilih objek wisata yang tepat, maka dibutuhkan sebuah sistem dalam bidang kepariwisataan. Sistem diharapkan dapat digunakan untuk mendapatkan informasi dan pengambilan keputusan pemilihan objek wisata secara efektif.

\section{TINJAUAN PUSTAKA}

2.1 Konsep Dasar Sistem

\subsubsection{Sistem}

Sistem berasal dari bahasa Latin systema dan bahasa Yunani sustema adalah suatu kesatuan yang terdiri dari komponen atau elemen yang dihubungkan bersama untuk memudahkan aliran informasi, materi atau energi untuk mencapai suatu tujuan. ${ }^{1}$ Sistem juga merupakan kesatuan bagian-bagian yang saling berkaitan serta memiliki item-item penggerak yang bertanggung jawab memproses masukan (input) sehingga menghasilkan keluaran (output). 


\subsubsection{Karakteristik Sistem}

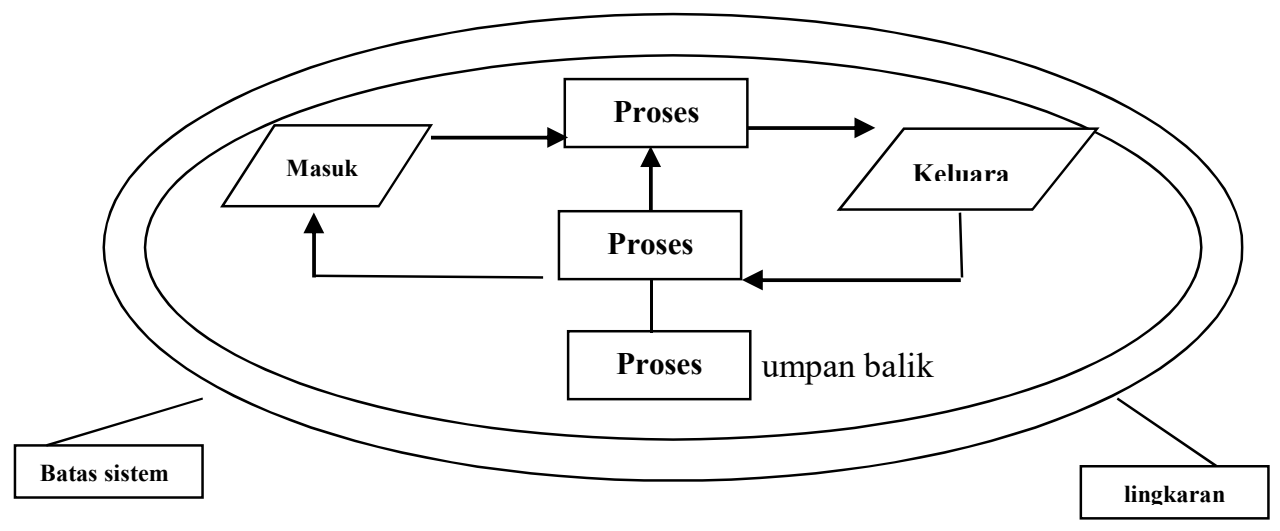

Gambar 2.1 Karakteristik Sistem

\subsection{Sistem Pendukung Keputusan ( SPK )}

Sistem Pendukung Keputusan merupakan suatu sistem interaktif yang membantu pengambil keputusan melalui penggunaan data dan model-model keputusann untuk memecahkan masalah-masalah yang sifatnya semi terstruktur dan tidak terstruktur. Dasar-dasar keputusan adalah sebagai berikut:

1. Intuisi, yaitu keputusan diambil berdasarkan perasaan dan pemikiran si pengambil keputusan.

2. Pengalaman, yaitu keputusan diambil berdasarkan kejadian-kejadian yang pernah dialami sebelumnya oleh si pengambil keputusan.

3. Fakta, yaitu keputusan diambil berdasarkan data dan informasi yang telah dikumpulkan.

4. Wewenang, yaitu keputusan diambil oleh pihak yang memiliki kekuasaan dan wewenang yang lebih tinggi.

5. Rasional, yaitu keputusan yang diambil harus logis atau dapat diterima akal sehat .

Konsep Sistem Pendukung Keputusan (SPK) pertama kali diperkenalkan pada awal tahun 1970-an oleh Michael S.Scott Morton dengan istilah Decisión System.

\subsection{Metode AHP}

\subsubsection{Penggertian AHP (Analitycal Hierarchy Proces)}

AHP merupakan suatu model pendukung keputusan yang dikembangkan oleh Thomas L.Saaty model pendukung keputusan ini akan menguraikan masalah multi factor atau multi kriteria yang kompleks menjadi suatu hirarki, hirarki didefenisikan sebagai suatu representasi dari sebuah permasalahan yang kompleks dalam suatu struktur multi level diamana level pertama adalah tujuan, yang diikuti level factor,kriteria, subkriteria, dan seterusnya kebawah sehingga

level terahir adalah alternatif. ${ }^{2}$

Peralatan utama Analitycal Hierarchy Process (AHP) adalah memiliki

sebuah hirarki fungsional dengan input utamanya persepsi manusia. Dengan hirarki, suatu masalah kompleks dan tidak terstruktur dipecahkan ke dalam kelomok-kelompoknya dan diatur menjadi suatu bentuk hirarki.

Dengan hirarki, suatu masalah yang kompleks dapat diuraikan kedalam kelompok-kelompoknya yang kemudian diatur menjadi suatu bentuk hirarki sehingga permasalahan akan tampak lebih terstruktur dan sistematis. AHP sering digunkan dalam metode pemecahan masalah dibanding dengan metode yang lain karena alasan-alasan berikut :

1. Struktur yang berhirarki, sebagai konsekuensi dari criteria yang dipilih, sampai pada subkriteria yang paling dalam.

2. Memperhitungkan validasi sampai dengan batas toleransi inkonsistensi berbagai kriteria alternativ yang dipilih oleh pengambil keputusan.

3. Memperhitungkan daya tahan output analisis sensitivitas pengambil keputusan

AHP juga memungkinkan struktur suatu sistem dan lingkungan ke dalam komponen yang saling berinteraksi dan kemudian menyatukan mereka dengan mengukur dampak pada komponen kesalahan sistem.

A. Prosedur AHP

1. Mendefinisikan masalah dan menentukan solusi yang diinginkan.

2. Membuat struktur hierarki yang diawali dengan tujuan utama. 
3. Membuat matriks perbandingan

Menggunakan skala rasio, dimana jika nilai matriks berada simetris dengan diagonalnya maka akan bernilai kebalikannya, atau dapat dirumuskan :

$$
\{\text { Aij }=1 / \text { Aij }\} \quad[2.1]
$$

Menjumlahkan setiap kolom ( $\Sigma$ kolom) pada matriks perbandingan.

4. Normalisasi matriks, dengan membagi setiap kolom matriks dengan jumlah kolom ( kolom), kemudian dijumlahkan setiap barisnya ( baris).

5. Menghitung total priority value (TPV) untuk mendapatkan bobot subkriteria.

6. Menghitung uji konsistensi untuk model AHP, matriks perbandingan dapat diterima jika nilai ratio consistency $(\mathrm{CR}) \leq 0.1(10 \%)$.

Tahapan dalam melakukan uji konsistensi adalah sebagai berikut:

a) Mengalikan nilai TPV dengan nilai kolom matriks pada nilai matriks perbandingan kemudian jumlahkan tiap barisnya.

b) Mencari consistency index (CI) dengan rumus:

$$
\{\mathrm{CI}=(\text { Imaks-n) } /(\mathrm{n}-1)\}
$$

Menjumlahkan setiap kolom ( kkolom) pada matriks perbandingan.

7. Normalisasi matriks, dengan membagi setiap kolom matriks dengan jumlah kolom ( $\Sigma$ kolom), kemudian dijumlahkan setiap barisnya ( baris).

8. Menghitung total priority value (TPV) untuk mendapatkan bobot subkriteria.

9. Menghitung uji konsistensi Untuk model AHP, matriks perbandingan dapat diterima jika nilai ratio consistency $(\mathrm{CR}) \leq 0.1(10 \%)$.

Tahapan dalam melakukan uji konsistensi adalah sebagai berikut:

a) Mengalikan nilai TPV dengan nilai kolom matriks pada nilai matriks perbandingan kemudian jumlahkan tiap barisnya.

b) Mencari consistency index (CI) dengan rumus:

$$
\{\mathrm{CI}=(\Sigma \text { maks-n }) /(\mathrm{n}-1)\}
$$

\subsubsection{Tahapan Metode AHP}

Dalam pengambilan keputusan ini penulis melakukan beberapa tahapan yaitu tahapan intelligent, tahapan modeling dan tahapan choice :

1. Tahapan Intelligent

Tahap intelligent adalah mengumpulkan serta menyusun kriteria pemilihan. Dalam kasus ini penulis pengukuran dalam memilih ada beberapa tahap yang harus diperhatikan yaitu:

1) Tentukan beberapa alternatif Pemilihan untuk menentukan kriteria,

2) Tentukan beberapa kriteria pemilihan.

3) Tentukan bobot kriteria pemilihan.

2. Tahapan Modeling

Pada tahap modilig model pendekatannya adalah Analytical Hierarchy

Process (AHP). Pada tahap ini ada beberapa hal yang harus diperhatikan yaitu:

1) Gambarkan Hierarchy keputusan Dalam Hierarchy keputusan ini yang akan dibahas, kriteria dan alternatif.

2) Tentukan bobot kriteriaberdasarkan persepsi pemilih.

3) Membuat matriks perbandingan kriteria persepsi pemilih.

\section{Tahapan Choice}

Pada tahangan dari setiap kriteria yang ada dengan mengalikan nilai bobot prioritas dari persepsi pemilih dengan bobot prioritas setiap alternatif.

\subsubsection{Prinsip Dasar Analitycal Hierarchy Process}

Dalam menyelesaikan permasalahn dengan AHP ada beberapa prinsip yang harus dipahami, diantaranya adalah sebagai berikut : 
1. Decomposition (membuat hirarki)

2. Comporative judgemnt (penilaian kriteria dan alternatif)

3. Sintesa prioritas

\subsubsection{Kelebihan dan kekurangan AHP}

Layaknya sebuah metode analisis, AHP memiliki kelebihan dan kekurangan dalam sistem analisisnya. Kelebihan-kelebihan analisis ini adalah :

1) Kesatuan (Unity)

2) Kompleksitas (Complexity)

3) Saling ketergantungan (inter defendece)

4) Struktur hirarki (hierarchy structuring)

5) Pengukuran ( Measurement)

6) Konsistensi ( consistency)

7) Sintesis ( synthesis)

8) Trade 0ff

9) Penilaian dan konsensus (judgement and consensus)

10) Penggulangan proses (penggulangan repetition)

Sedangkan kekurangan dari metode AHP ini adalah Ketergantungan model AHP pada input utamanya. Input utama ini berupa persepsi seorang ahli sehingga dalam hal ini melibatkan subyektifitas sang ahli selain itu juga model menjadi tidak berarti jika ahli tersebut memberikan penilaian yang keliru.Metode AHP hanya metode matematis tanpa ada pengujian secara statistik sehingga tidak ada batas kepercayaan dari kebenaran model yang terbentuk.

\subsection{Defenisi Basis Data}

Basis data (database) adalah sekumpulan data yang saling berhubungan satu dengan yang lainya yang diorganisasikan berdasarkan sebuah skema atau struktur tertentu, tersimpan di hardware komputer dan dengan software untuk melakukan manipulasi untuk kegunaan tertentu.

Adapun tujuan dari basis data adalah sebagai berikut :

1. Kecepatan dan kemudahan (speed)

2. Efisiensi ruang penyimpanan (space)

3. Keakuratan (accuracy)

4. Ketersediaan (availabiliti)

5. Kelengkapan (completeness)

6. Keamanan (security)

7. Kebersamaan pemakaian (sharability) 


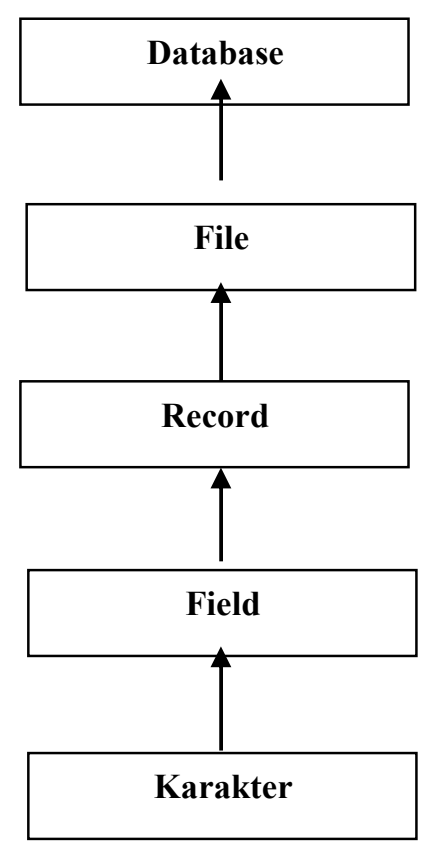

Gambar 2.3 Urutan Data

\begin{tabular}{|l|l|l|l|}
\hline Field name & Type data & Size & Keterangan \\
\hline Id & Auto_number & 12 & Primary key \\
\hline Nama & Text & 25 & \\
\hline Ttl & Date & 20 & \\
\hline
\end{tabular}

Tabel 2.3 Contoh Table Database

\subsection{DBMS ( Database Management System )}

DBMS adalah suatu sistem atau perangkat lunak yang dirancang untuk mengelola suatu data dan menjalankan operasi terhadap data yang diminta bnayak pengguna. DBMS merupakan perangkat lunak yang dirancang untuk dapat melakukan utilisasi dan mengelola koleksi data dalam jumlah nyang besar.

Komponen utama DBMS dapat dibagi menjadi :

1. Hardware

2. Software

3. Prosedur

4. Data

5. User

\subsection{Defenisi DfD (Data Flow Diagram)}

Data Flow Diagram (DFD) adalah alat pembuatan model yang memungkinkan profesional sistem untuk menggambarkan sistem sebagai suatu jaringan proses fungsional yang dihubungkan satu sama lain dengan alur data, baik secara manual maupun komputerisasi. DFD ini sering disebut juga dengan nama Bubble chart, Bubble diagram, model proses, diagram alur kerja, atau model fungsi.

Didalam DFD terdapat 3 level, yaitu :

\section{Diagram Konteks}

menggambarkan satu lingkaran besar yang dapat mewakili seluruh proses yang terdapat di dalam suatu sistem. Merupakan tingkatan tertinggi dalam DFD dan biasanya diberi nomor 0 (nol). Semua entitas eksternal 
yang ditunjukkan pada diagram konteks berikut aliran-aliran data utama menuju dan dari sistem. Diagram ini sama sekali tidak memuat penyimpanan data

\section{Diagram Nol (diagram level-1)}

merupakan satu lingkaran besar yang mewakili lingkaran-lingkaran kecil yang ada di dalamnya. Merupakan pemecahan dari diagram Konteks ke diagram Nol. di dalam diagram ini memuat penyimpanan data.

\section{Diagram Rinci}

merupakan diagram yang menguraikan proses apa yang ada dalam diagram Nol.

Berikut ini merupakan simbol-simbol yang biasanya digunakan pada Data Flow Diagram (DFD)

Gane / Sarson
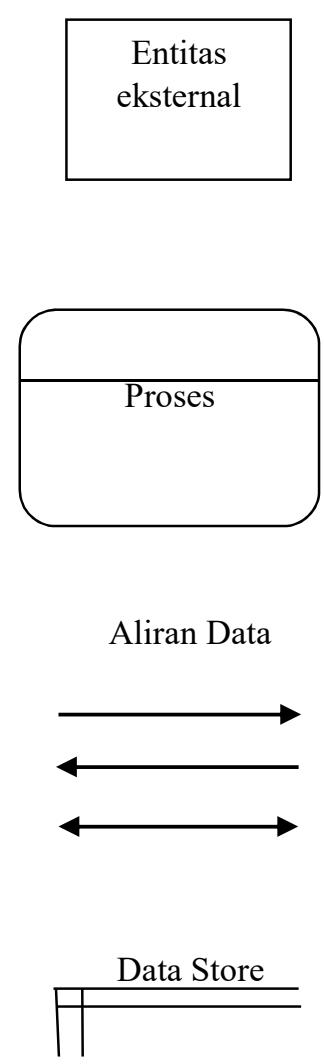

Yourdon / Do Marco
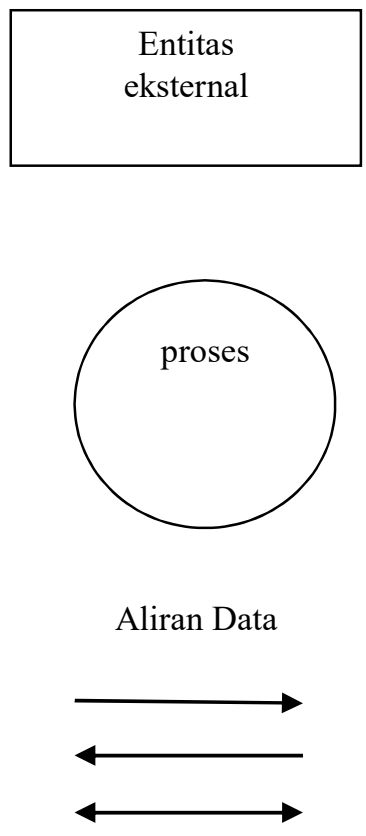

Data Store
Keterangan

Entitas eksternal dapat berupa

orang/ unit terkait yang berinteraksi dengan sistem tetapi diluar sistem.

Orang/ unit yang mempergunakan atau melakukan transformasi data. Komponen fisik tidak di identifikasikan

Aliran data dengan arah khusus dari sumber ketujuan

Penyimpanan data atau tempat data dilihat oleh proses

\subsection{Defenisi Entity Relationship Diagram (ERD)}

ERD adalah sebuah model data yang didasarkan atas presepsi dunia nyata, yang terdiri atas object dasar yang disebut dengan entitas dan hubungan (relation) antar object-object tersebut. Model ini dirancang untuk menggambarkan persepsi dari pemakai dan berisi obyek-obyek dasar yang disebut entity dan hubungan antar entity - entity tersebut yang disebut relationship. Diagram Entity - Relationship melengkapi penggambaran grafik dari struktur logika. Dengan kata lain Diagram E-R menggambarkan arti dari aspek data seperti bagaimana entity - entity, atribut - atribut dan relationship - relationship disajikan.

\subsection{Defenisi java}

Java adalah nama salah satu bahasa pemograman computer yang berorientasi objek, diciptakan oleh satu tim perusahaan Sun Microsystem, perusahaan workstation UNIX (Sparc) yang cukup terkenal. Java diciptakan berdasarkan bahasa $\mathrm{C}++$, dengan tujuan Platform independent (dapat dijalankan pada berbagai jenis hardware tanpa kompilasi ulang), dengan slogan Write Once Run Anywhere (WORA). Dibandingkan bahasa C++, Java pada hakikatnya lebih sederhana dan memakai objek secara murni. ${ }^{6}$ Aplikasi dengan berbasis Java ini dikompulasikan ke dalam p-code dan bisa dijalankan dengan Java Virtual Machine. Fungsionalitas dari Java ini dapat berjalan dengan platform sistem operasi yang berbeda karena sifatnya yang umum dan non-spesifik.

\subsection{NetBeans}

Netbeans merupakan sebuah aplikasi Integrated Development Environment (IDE) yang berbasiskan Java dari Sun Microsystems yang berjalan di atas swing? ${ }^{7}$. Swing merupakan sebuah teknologi Java untuk 
pengembangan aplikasi desktop yang dapat berjalan pada berbagai macam platform seperti windows, linux, Mac OS X dan Solaris. Sebuah IDE merupakan lingkup pemrograman yang di integrasikan ke dalam suatu aplikasi perangkat lunak yang menyediakan Graphic User Interface (GUI), suatu kode editor atau text, suatu compiler dan suatu debugger.

Netbeans juga digunakan oleh sang programmer untuk menulis, meng-compile, mencari kesalahan dan menyebarkan program netbeans yang ditulis dalam bahasa pemrograman java namun selain itu dapat juga mendukung bahasa

pemrograman lainnya dan program ini pun bebas untuk digunakan dan untuk

membuat professional desktop, enterprise, web, and mobile applications dengan Java language, $\mathrm{C} / \mathrm{C}++$, dan bahkan dynamic languages seperti PHP, JavaScript, Groovy, dan Ruby.

\subsection{Defenisi MySQL}

MySQL adalah salah satu jenis database server menggunakan SQL sebagai bahasa dasar untuk mengakses databasenya. Selain itu ia bersifat open source (anda tidak perlu membayar untuk menggunakannya). ${ }^{8}$ Berdasarkan riset dinyatakan bahwa bahwa di platform Web, dan baik untuk kategori open source maupun umum, MySQL adalah database yang paling banyak dipakai. Menurut perusahaan pengembangnya, MySQL telah terpasang di sekitar 3 juta komputer. Puluhan hingga ratusan ribu situs mengandalkan MySQL bekerja siang malam memompa data bagi para pengunjungnya.

\section{METODELOGI PENELITIAN}

Penelitian ini dimulai dengan Menganalisis sistem, adapun analisis yang dibutuhkan adalah:

\section{Analisis kebutuhan sistem}

Tujuan dari analisis kebutuhuhan sistem adalah untuk mengetahui kebutuhan sistem baru baik dari segi kebutuhan perangkat keras maupun kebutuhan akan perangkat lunak sehingga nantinya sistem yang baru dapat berjalan dengan baik.

\section{Analisis Kebutuhan Perangkat Keras}

Untuk membuat dan menerapkan sistem yang baru dibutuhkan 1 unit komputer / laptop dengan spesifikasi sebagi berikut :

1. CPU Intel Core To Three Atau Setara

2. RAM DDR2 2 GB

3. Hardisk 320 GB HDD

4. Keyboard

5. Mouse

\section{Analisis kebutuhan perangkat lunak}

Beberapa perangkat lunak yang digunakan penulis untuk membangun sistem yang baru adalah sebagi berikut:

1. Linux ubuntu sebagai operating system

2. MySQL sebagai database server.

3. Pemograman java

\section{Analisis kebutuhan informasi}

Informasi adalah salah satu alasan mengapa sistem baru ini layak diterapkan, karena mempermudah wisatawan dalam pemilihan objek wisata dengan cepat dan data yang diberikan akurat.

\section{Analisis kebutuhan pengguna user}

\section{Analisis kelayakan sistem}

Ada beberapa analisis yang akan dilakukan dalam tahapan ini, antara lain sebagai berikut:

1. Analisis Kelayakan Teknologi 
Sistem baru yang diusulkan saat ini sangat layak jika dipandang dari segi teknologi karena penyampaian data yang sudah tersimpan lalu dikirimkan informasi pemanggilan yang akan diperiksa langsung melalui media teknologi sms, sehingga penggiriman data lebih cepat dan murah.

2. Analisis Kelayakan Operasional

Sistem ini lebih mudah digunakan karena dari segi interface sangat mudah dipahami, sehingga akan membantu pariwisata dalam pengoprasianya.

Langkah Selanjutnya yang akan dikerjakan adalah perancangan sistem, adapun tahap perencanaan ini merupakan tahap awal dalam membangun sebuah aplikasi seperti membuat tabel basis data,relasi antar tabel, erd,dfd, dan rancangan interface. Ada beberapa prosedur dalam menggunakan metode AHP yaitu:

1. Menyusun hirarki dari permasalahan yang dihadapi.

2. Menentukan prioritas elemen dengan langkah penyelesaian sebagai berikut:

- Tetapkan permasalahan, kriteria dan sub kriteria (jika ada), dan alternative pilihan.

1) Permasalahan : Menentukan kriteria objek wisata.

2) Kriteria : harga, fasilitas, jarak, keamanan, kebersihan

3) Subkriteria : : Sangat Tinggi: 86-100 Tinggi:70-85, Cukup: 56-

69 Rendah: 40-55,Sangat Rendah: 0-39.

- Membentuk matrik Pairwise Comparison,kriteria.

- Menentukan rangking kriteria dalam bentuk vector prioritas (disebut juga eigen vector ternormalisasi).

- Untuk matrik Pairwise Comparison sub kriteria, saya asumsikan memiliki nilai yang sama dengan matrik Pairwise Comparison kriteria.

- Terakhir adalah menentukan rangking dari alternatif dengan cara menghitung eigen vector untuk tiap kirteria dan sub kriteria. Gunakan tabel nilai analisis objek wisata yang telah ditetapkan :

a. Data wisata yang menjadi pilihan

Nilai Kriteria didapat dari hasil analisis objek wisata yang telah di tetapkan oleh pihak pengelola.

Hasil dari adalah penjumlahan dari $\mathrm{H}+\mathrm{FS}+\mathrm{JR}+\mathrm{KA}+\mathrm{KB}$

\begin{tabular}{lccccccc}
\multicolumn{1}{c}{\begin{tabular}{c} 
Nama \\
\multicolumn{1}{c}{ objek wisata }
\end{tabular}} & H & FS & JR & KA & KB & Total & Bobot nilai objek wisata \\
Ujung paking & 90 & 90 & 80 & 90 & 90 & 440 & 88 \\
Pante menye & 80 & 70 & 80 & 80 & 80 & 390 & 78 \\
Atu belah & 70 & 70 & 80 & 80 & 80 & 350 & 70 \\
Putri pukes & 70 & 70 & 70 & 80 & 80 & 370 & 74 \\
Mengaya & 80 & 70 & 80 & 80 & 90 & 400 & 80 \\
Mepar & 80 & 70 & 80 & 80 & 70 & 380 & 76 \\
Goa loyang koro & 70 & 70 & 80 & 70 & 70 & 360 & 71 \\
Waterpak Toa & 90 & 80 & 80 & 80 & 80 & 410 & 83 \\
Pantan terong & 80 & 70 & 70 & 70 & 70 & 360 & 72 \\
Pante gemasih & 90 & 80 & 70 & 90 & 90 & 420 & 84 \\
Pante ketibung & 90 & 90 & 80 & 80 & 90 & 430 & 86 \\
Piyoh tedoh & 90 & 90 & 80 & 80 & 80 & 420 & 81
\end{tabular}

Hasil dari nilai bobot $=$ total $/$ jumlah kriteria 


Waterparkmininawi
$\begin{array}{rllllll} & 90 & 90 & 70 & 70 & 90 & 410 \\ & =440 / 5 \\ & =88\end{array}$

\section{b.Tabel Rangking}

\begin{tabular}{lcc}
$\quad$ Nama & Nilai & Rangking \\
\multicolumn{1}{c}{ objek wisata } & & \\
Ujung paking & 88 & 1 \\
Mengaya & 86 & 2 \\
Waterpak Toa & 84 & 3 \\
Pante menye & 83 & 4 \\
Mepar & 82 & 5 \\
Waterparkmininawi & 81 & 6 \\
Pante gemasih & 80 & 7 \\
Pante ketibung & 78 & 8 \\
Piyoh tedoh & 76 & 8 \\
Pantan terong & 74 & 10 \\
Putri pukes & 72 & 11 \\
Atu belah & 71 & 12 \\
Goa loyang koro & 70 & 13
\end{tabular}

\section{Gambar 3.8 Form Nilai Bobot Objek Wisata}

\section{HASIL DAN PEMBAHASAN}

Tampilan utama saat aplikasi dijalankan adalah sebagai berikut :

1. Untuk membuka database ketikkan pada url seperti gambar berikut ini

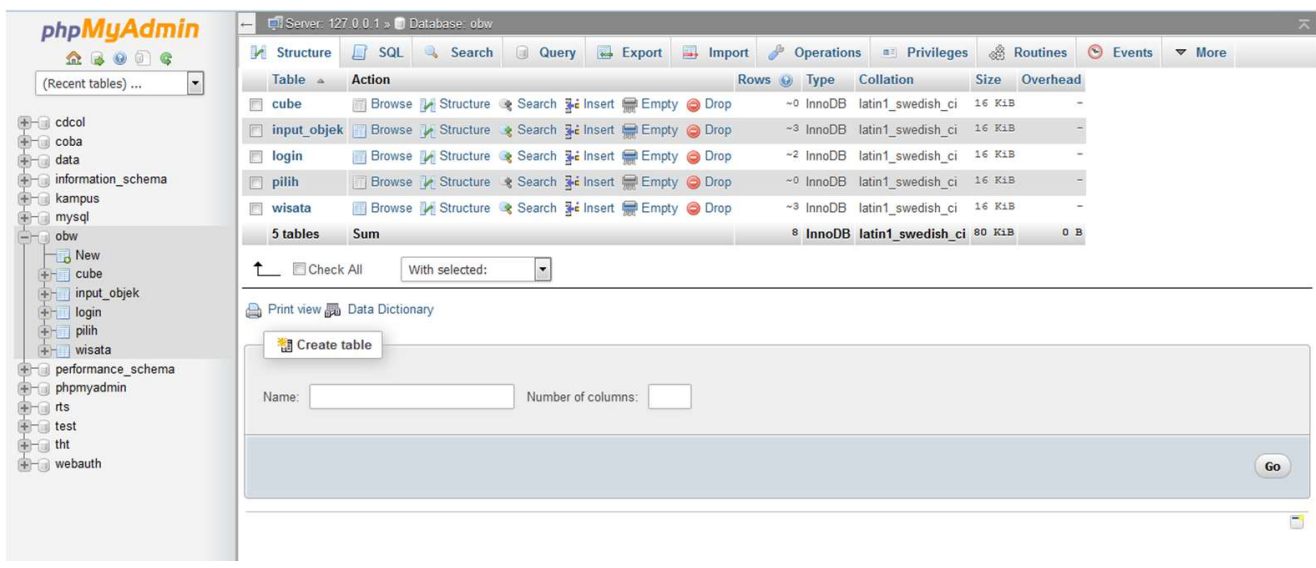

Gambar 4.1 Database PhpMyAdmin 
2. Untuk menjalankan aplikasi, anda harus membuka aplikasi seperti gambar dibawah ini

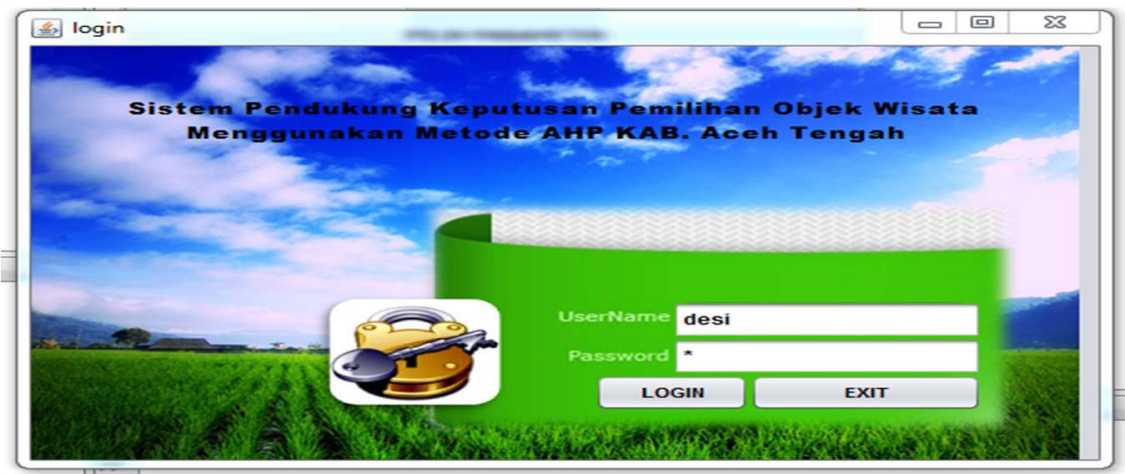

\section{Gambar 4.2 Form Login}

3. Menu utama

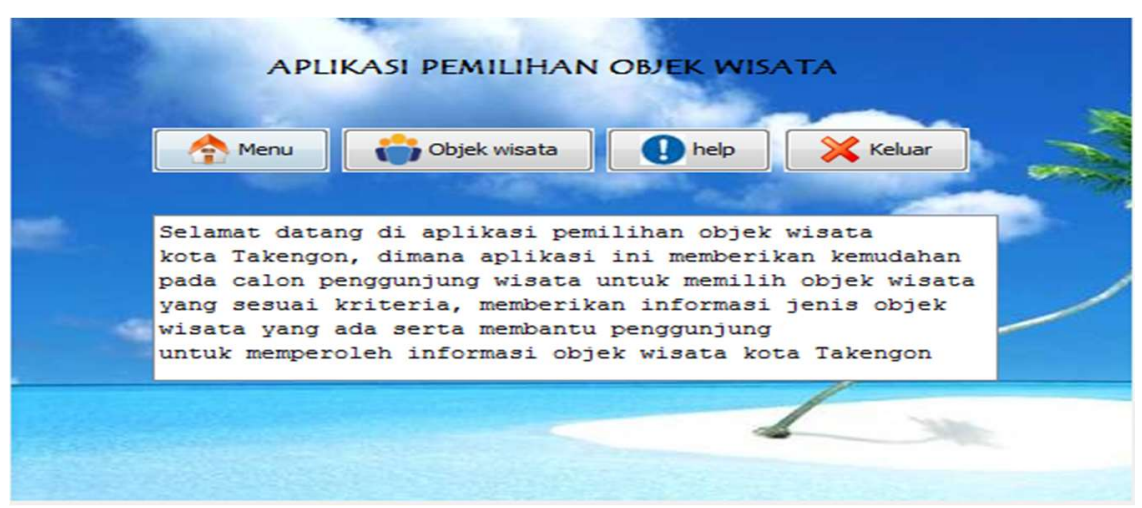

\section{Gambar 4.3 Form Menu Utama}

4. Form Menu

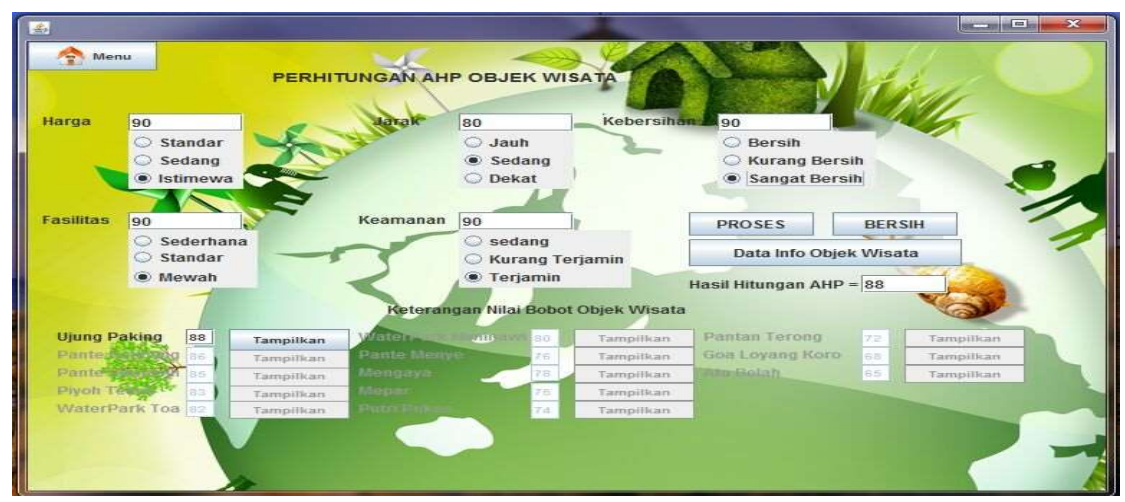

Klik data info objek wisata maka akan muncul form pada gambar dibawah ini

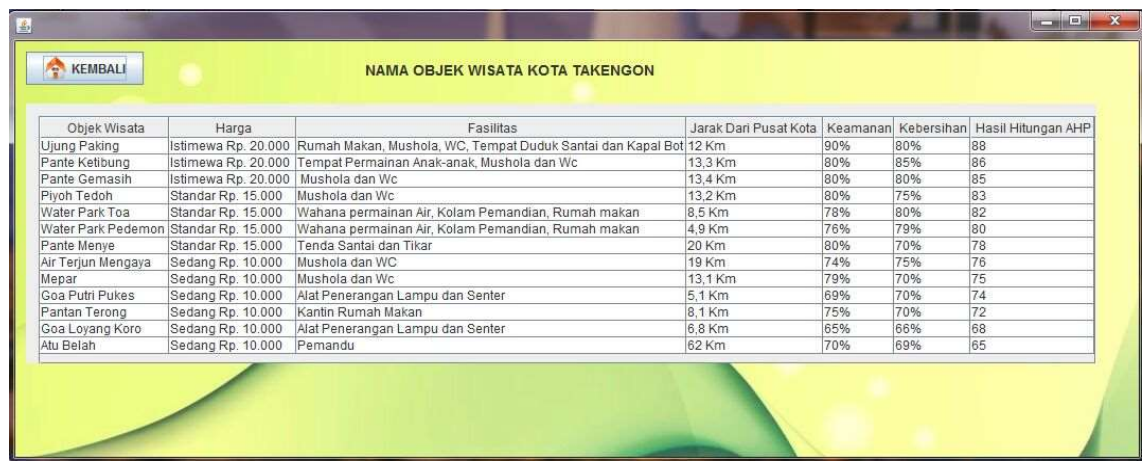


5. Form Hasil Solusi

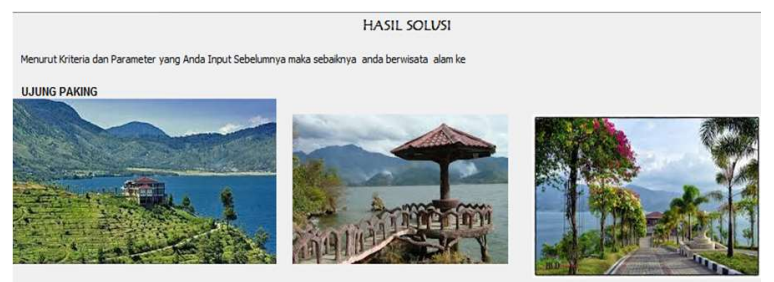

UJurs Pexing mefupakan salah satu tempat wisata di Takengon, Aceh Tengah. Tempat wisata ini
digredikg1 bakalan ramai dikanjung1 wisatawan di tahun baru. Pasalnya, pada har1 blasa dan har1

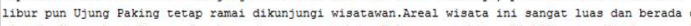
tempat wisaca ini dikenakan biaya karcis sebesar Ro5 ribu setiap orang. Lalu ditambah biaya parkir $=$ kenderaan roda dua kp5 ribu dan kenderaan roda empat Rp10 ribu. Saat memasuk1 Ujung Paking, harus melalui
telah ditatata yang menurun.

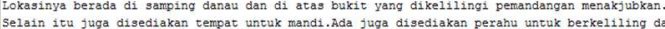
Selain itu juga disediakan tempat untuk mandi.Ada juga disediakan perahu untuk berkeliling danau.
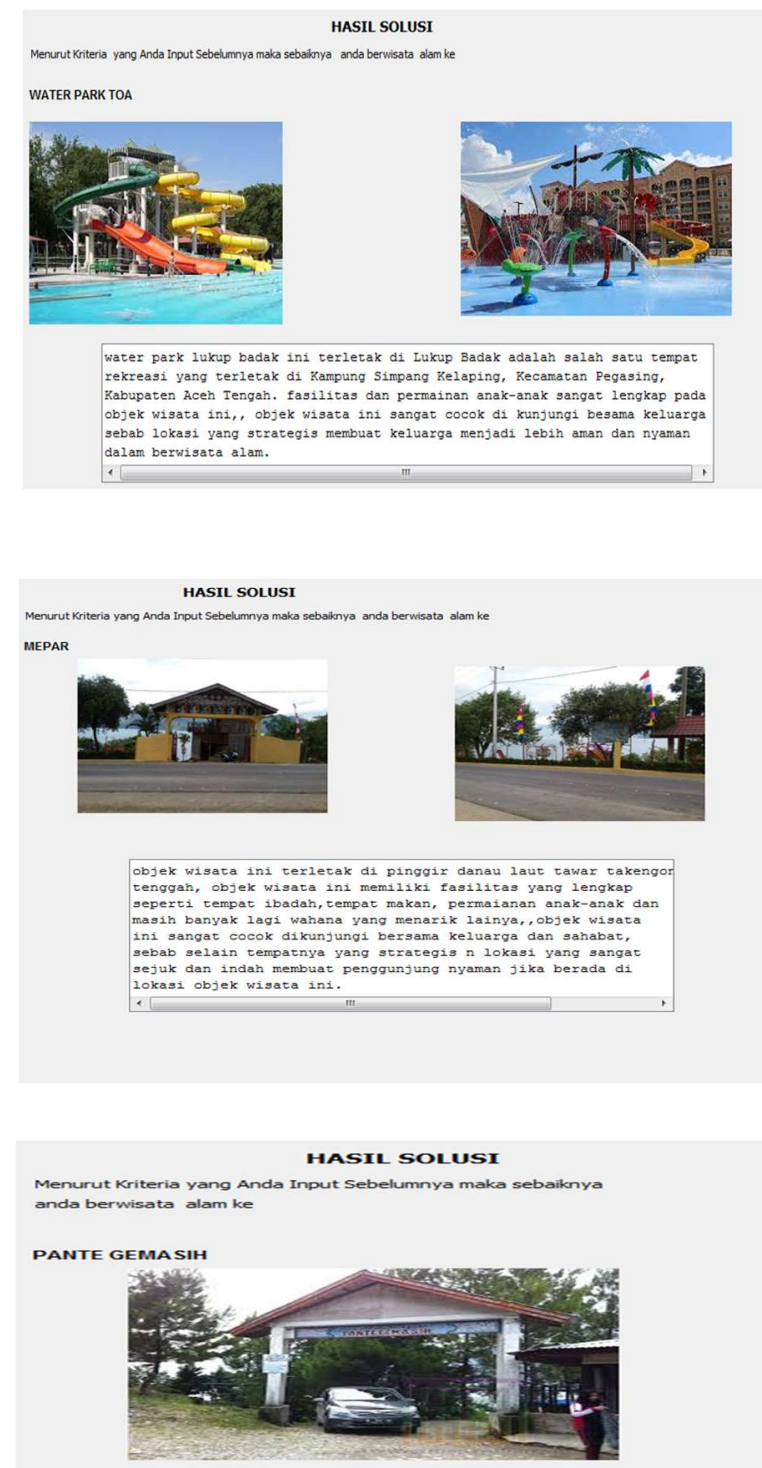

pante gemasin (pantai baik) terletar dipinggi yang seluk disebabkan banya memiliki tempat terdapat pada lokasi objek wisata ini, lokasi yang
strategis dan langsung berdekatan dengan alx ini Terategis pan langung bexdekatan denga
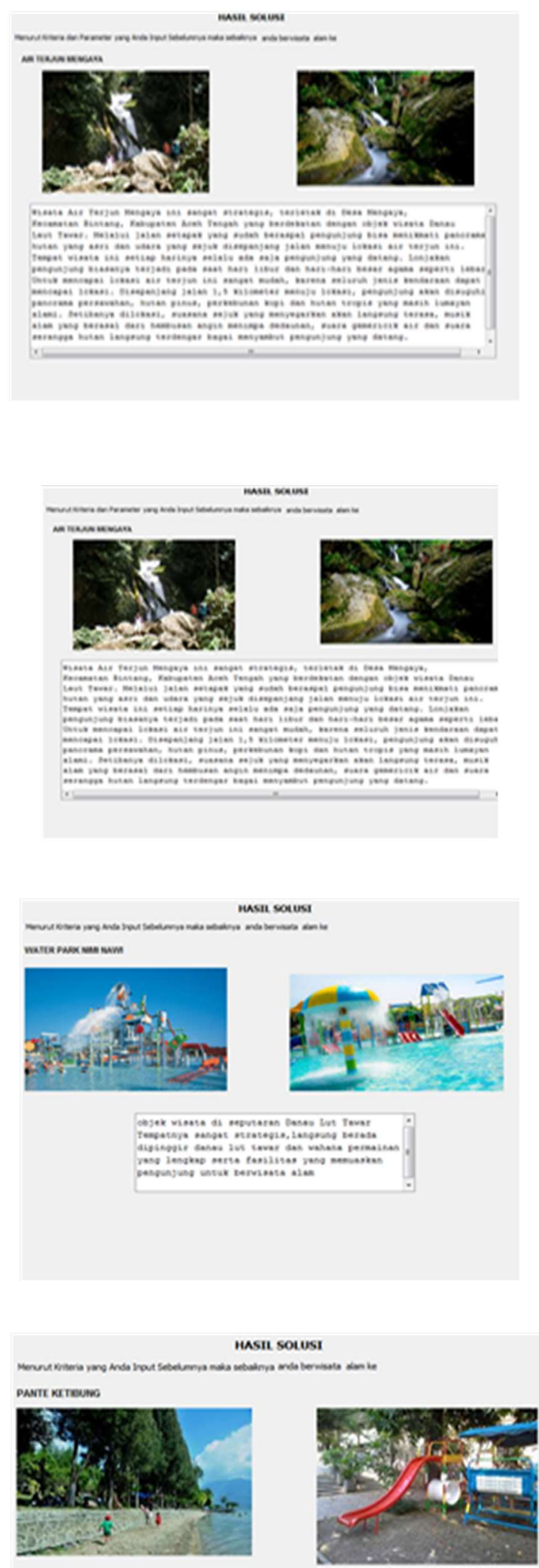

20kasi cojex visats yesa satu las tosak kalah menarik juga pads

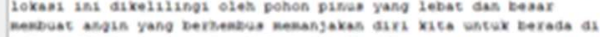

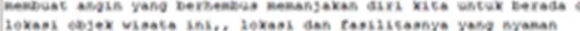

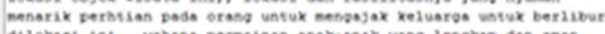
dilokasi iss,. vahano permainan anak-asex yang lengkep dan aman 

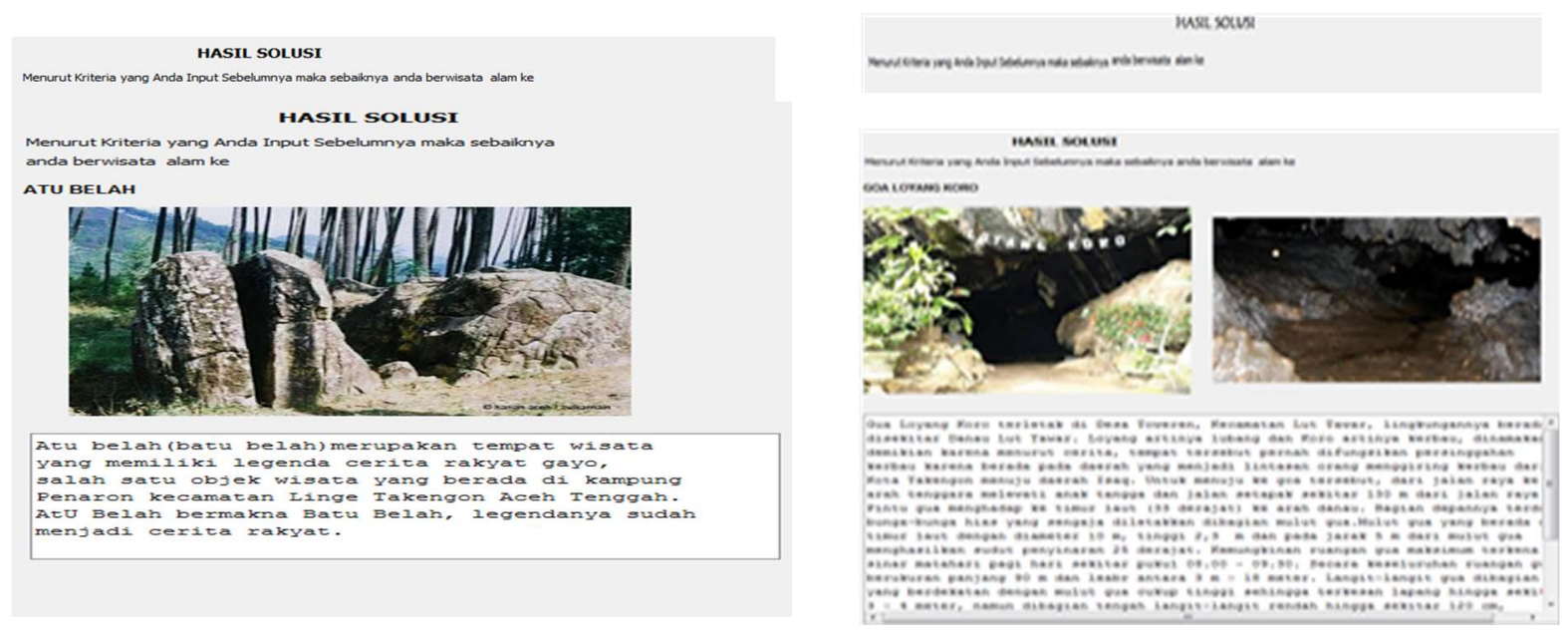

\section{Gambar 4.5 Form Hasil Solusi}

6. Menu Objek Wisata

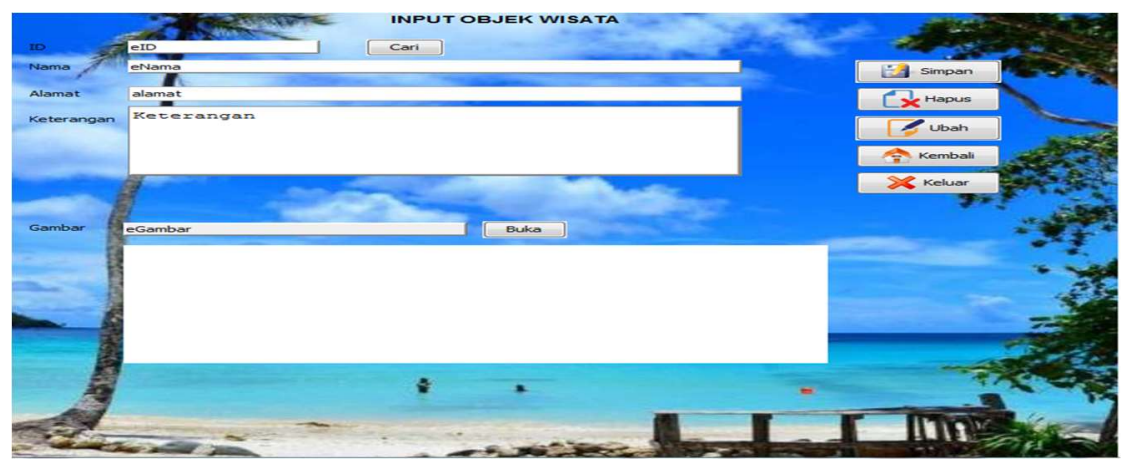

Gambar 4.6 Form Menu Objek Wisata

7. Menu Help

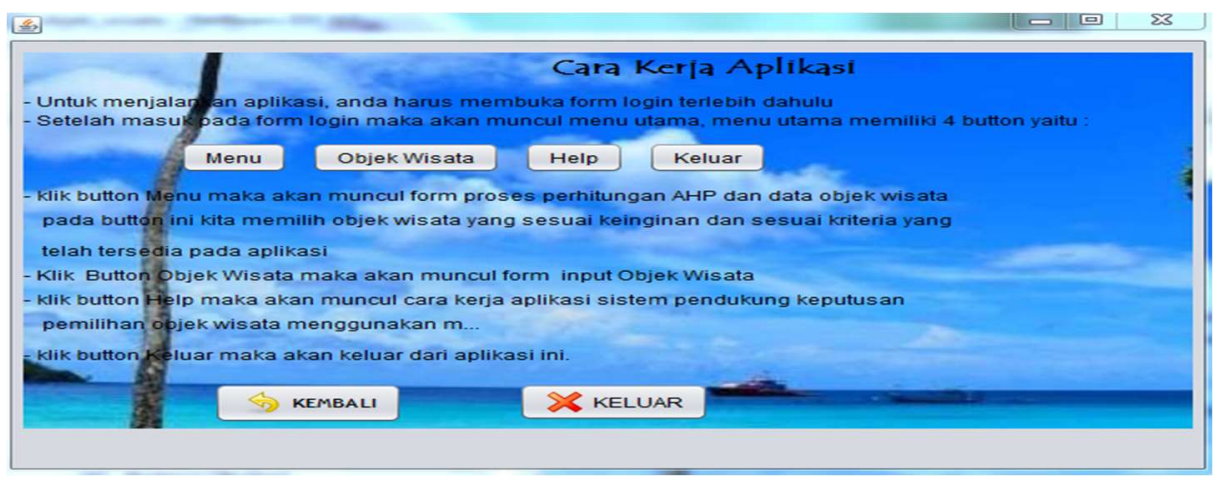

\section{Gambar 4.7 Form Menu Help}

\section{KESIMPULAN DAN SARAN}

Kesimpulan yang dapat diperoleh dari penelitian ini adalah:

1. Memberi kemudahan pada calon pengunjung wisata untuk memilih obyek wisata

yang sesuai kriteria dengan menerapkan metode AHP (Analitycal Hierarchy Process )

2. Memberi informasi jenis dan obyek wisata

3. Mengetahui beberapa kriteria yang menjadi daya tarik bagi calon pengunjung wisata dalam mengunjungi obyek wisata 
Saran-saran yang dapat diberikan berdasarkan hasil penelitian dan sistem pendukung keputusan yang telah dibuat, maka peneliti menyarankan agar interface aplikasi dibuat lebih bagus sehingga memberikan kesan lebih menarik dan harapan penelitian lebih luas lagi dibidang pariwisata sehingga mempermudah pengolahan data informasi lainya.

\section{DAFTAR PUSTAKA}

[1] Bangunan Dan Kawasan Cagar Budaya Kota Bandung Di

Disbudpar Kota Bandung, Vol 2,No 2,2013.

[2] Bima Ifnu,Java Dekstop, 2008 hal. 5

[3] Evan Jaelani 2011. Analitical hierarchy proses.Bandung. Hal 115 Hariman Irman dkk, aplikasi pendukumg keputusan dalam menentukan objek wisata alam menggunkan metode AHP berbasis android, vol 1, no 1,2014.

[4] kadir Abdul dasar pemograman web dinamis menggunakan php, 2009, hal:348

[5] Kosasi Sandy jurnal Sistem Penunjang Keputusan Memilih Paket Wisatadengan Metode Case-Based Reasoning, Vol 3,No 2,2013.

[6] Saragih Hartati Sylvia jurnal,Penerapan Metode Analitycal Hierarchy Process (Ahp) Pada Sistem Pendukung Keputusan Pemilihan Laptop, Vol IV, No

[7] Sardi Umasugi dkk, tahun 2013 yang berjudul (Studi Pengembangan Potensi Objek Wisata Anyar Mangrove (Wam) Dikelurahan Gunung Anyar Tambak Surabaya, Vol 11,No 1,2013.

[8] Sutedjo.Perencanaan dan Pengembangan Sistem Informasi.2004 hal:49

[9] Suarga.Dasar Pemograman Komputer dalam Bahasa Java,2009 hal.2

[10] Sudyatmika Aditya Wayan dkk jurnal,Pengembangan Sistem Pendukung Keputusan Berbasis Android Untuk Penentuan Daerah Tujuan Wisata Di Bali Dengan $\quad$ Menggunakan Metode Fuzzy Tahani, Vol 4, No 4, Tahun 2015.

[11] Prabowo Dhimas Syahrani dkk jurnal,Sistem Pendukung Keputusan Revitalisasi Terhadap Bangunan Dan Kawasan Cagar Budaya Kota Bandung Di Disbudpar Kota Bandung, Vol 2,No 2,2013.

[12] http://id.wikipedia.org/wiki/Sistem

[13] http://dimas347.wordpress.com/2010/12/08/karakteristik-sistem/

[14] http://artipengetahuan.blogspot.com/2013/02/pengertian-sistem-pendukungkeputusan.html. 